\title{
Erratum zu: Ungerechte Bildung und Suche nach Potenzialitäten - Forschungsstand, Erklärungsansätze und Fragestellung
}

\section{Erratum zu:}

Kapitel 2 in: F. Weitkämper, Lehrkräfte und soziale Ungleichheit, Bildung und Gesellschaft, https://doi.org/10.1007/978-3-658-24483-5_2

Vollständig überarbeiteter und korrigierter Text auf S. 64. 